\title{
Bone Cancer pN1 TNM Finding v7
}

National Cancer Institute

\section{Source}

National Cancer Institute. Bone Cancer pN1 TNM Finding v7. NCI Thesaurus. Code C88437.

Bone cancer with regional lymph node metastasis. (from AJCC 7th Ed.) 